\title{
DOKTRIN MISTISISME AL-GHAZALI (SUFISME SEBAGAI ETAPE PERJALANAN SPIRITUAL)
}

\author{
Syihabul Furqon'; Busro ${ }^{2}$ \\ ${ }^{1,2}$ UIN Sunan Gunung Djati Bandung \\ E-mail: syihabulhajj2@gmail.com
}

\begin{abstract}
ABSTRAK
Pada periode Seljuk, dinasti Abasiyah, fakultas-fakultas pengetahuan berkembang sedemikian rupa. Filsafat, kalam, tafsir, yurisprudensi Islam dan mistisisme mengemuka; demikian pula hanya dengan friksi dan sentimen yang saling bertentangan. Pada periode ini, signifikansi dari doktrin Al-Ghazali atas empat diskursus fakultas Islam utama meliputi filsafat, teologi, yurisprudensi dan mistisisme didudukkan dan dikodifikasi sedemikian rupa. Filsafat, setlah serangan Al-Ghazali yang dianggap meruntuhkan dasar filosofis terbukti keliru. Sebab mistisisme filosofis dipostulatkan sejak periode AlGhazali dan mendorong penelaahan metafisika sampai pada puncaknya di tangan Ibn 'Arabi kelak. Pada satu aspek lain Al-Ghazali mendamaikan friksi di kalangan yurisprudensi Islam yang cenderung tekstual-dognatis dengan kalangan yang pada masa itu dinafikan kesahihannya: mistisisme Islam (sufisme). Signifikansi Al-Ghazali dalam ranah-ranah ini berimplikasi luas sampai saat ini; dan mendorong sebagai apa yang tersirat dalam otobiografi spiritualnya sebagai: etape perjalanan spiritual.
\end{abstract}

\section{KATA KUNCI}

Filsafat; Mistisisme; Teologi; Mistisisme Filosofis; Spiritualitas

\begin{abstract}
In the Seljuk period, the Abasiyah dynasty, the faculties of knowledge developed in such a way. Philosophy, Kalam, Interpretation, Islamic jurisprudence and mysticism surfaced; as well as with contradictory frictions and sentiments. In this period, the significance of Al-Ghazali's doctrine of the four main Islamic faculty discourses including philosophy, theology, jurisprudence and mysticism was seated and codified in such a way. Philosophy, after the attack of Al-Ghazali which is considered to undermine the philosophical foundation proved wrong. For philosophical mysticism postulated since the Al-Ghazali period and encouraged the study of metaphysics to its culmination in the hands of Ibn 'Arabi later. In another aspect Al-Ghazali reconciled the friction among Islamic jurisprudence that tends to be textual-dognatical to the circle that at that time denied its validity: Islamic mysticism (sufism). The significance of Al-Ghazali in these domains has widespread implications to date; and encourages as implied in his spiritual autobiography as: the stage of spiritual journey.
\end{abstract}

\section{KEYWORDS}

Philosophy; Mysticism; Theology; Philosophical Mysticism; Spirituality. 


\section{A. BIOGRAFI SPIRITUAL AL-GHAZALI}

Abu Hamid Muhammad Ibn Muhammad AlGhazali lahir di Thus sebuah kota kecil di Khurasan, Persia (Iran sekarang, yang kini wilayahnya disebut Meshed $)^{1}$, pada 450H/1058M ${ }^{2}$, tiga tahun setelah kaum Seljuk mengambil alih kekuasaan di Bghdad dan seperempat abad setelah meninggalnya Ibn Sina. Bisa dikatakan bahwa rentang hidup AlGhazali berkaitan erat dengan nasib dinasti ini, yang kekuasaannya meluas di seluruh Iran dan bagian-bagian Anatolia sebelah timur. ${ }^{3}$

Dikisahkan, ayahnya adalah seorang pecinta ilmu pengetahuan, taat beribadah dan menyenangi para ulama disamping aktif menghadiri halaqah sufi. Namun kondisinya yang sudah lanjut tak memungkinkan untuk menggeluti ilmu pengetahuan dan mengajari para putranya karena tak bisa menulis dan keterbatasan ekonomi. Akan tetapi ia menginginkan kedua anaknya (Al-Ghazali dan Ahmad) menimba banyak ilmu pengetahuan. Karenanya sebelum ayahnya meninggal dunia, semasa Al-Ghazali masih kecil, beliau dan saudaranya Ahmad telah diserahkan kepada seorang ahli tasawuf sekaligus sahabatnya, yang pada fase inilah Al-Ghazali dipersiapkan dasar-dasar agamanya sedari dini. Sang sufi inilah yang mendidik Al-Ghazali dengan keteladanan akhlak, mengajarinya bahasa Arab dan Persia, serta membaca Al-Qur'an sebagai pelajaran dasar. Dalam wasiat sang ayah, seraya menitipkan sedikit harta pada sufi tersebut menuturkan; "Aku menyesal sekali karena aku tidak belajar menulis. Aku berharap untuk mendapatkan itu untuk kedua putraku ini.",

Tak lama berselang, ayahnya meninggal dunia. Pada masa kecil, Al-Ghazali hidup

\footnotetext{
${ }^{1}$ Sulaiman Dunya, Al-Haqiqah fi Naddzri al-Ghazali, Kairo: Darul Ma'aarif, 1971, hlm. 18.

${ }^{2}$ Mengenai tahun kelahiran Al-Ghazali sendiri para sarjanawan sedikit berbeda dalam memberi tahun Masehi, sebagian mencatat 1058, sebagaian lainnya 1059. Lihat, Ahmadie Thaha, dalam pengantar terjemah Tahafut al-Falasifah, Jakarta: Pustaka Panjimas, 1985, hlm. xiv. Lihat, Dr, Mahmud Hamdi Zaqzuq, Al-Ghazali Sang Sufi Sang Filosof, Bandung: Pustaka, 1987, hlm. 8.
}

dalam kemiskinan karena harta peninggalan ayahnya habis oleh biaya menimba ilmu. Guru mereka, juga karena kondisi ekonomi yang terbatas, kemudian menyarankan kepada keduanya untuk melanjutkan belajar pada salah satu sekolah di kotanya, dan mereka melanjutkan sekolah di sana tanpa dipungut biaya (semacam program asrama bagi para pelajar). Hanya saja, yang mencolok di atara Al-Ghazali dan Ahmad adalah bahwa AlGhazali lebih antusias pada pengetahuan lebih lanjut. Al-Ghazali mengembangkan dirinya untuk mempelajari berbagai ilmu pengetahuan sedangkan Ahmad semakin terlihat menggeluti dunia spiritual. Kecenderungan Ahmad yang terakhir inilah yang kelak oleh sebagian ilmuwan disinyalir memberikan andil dalam bergesernya haluan Al-Ghazali dalam mencari dan mendapatkan keyakinan.

Di Thus, pada saat usia Al-Ghazali sekitar tujuh tahun, ia mempelajari berbagai ilmu pengetahuan, terutama fiqh, tafsir dan hadits pada Imam ar-Razakani. ${ }^{5}$ Demi melanjutkan pendidikannya ke tingkat yang lebih tinggi, yakni mempelajari ilmu fiqh tingkat lanjut, AlGhazali harus pergi ke Jurjan, 160-km dari Thus. Pada saat itu usianya sekitar 15 tahun dan gurunya di kota itu bernama Abu Nashr Isma'ili. Di Jurjan ia tinggal selama lima tahun.

Kemudian ia kembali lagi ke kota kelahirannya untuk mengendapkan apa yang telah dipelajarinya, terutama yang berkenaan dengan masalah-masalah fiqh. Setelah tiga tahun lamanya, saat ia berusia 23 tahun, AlGhazali pergi ke Naisabur pada saat Imam alHaramain (Abu Al-Ma'ali Al-Juwaini) yang bermazhab Asy'ariyah, menjabat sebagai kepala Madrasah Nidzhamiyah di Baghdad. Al-Ghazali muda menghabiskan masa-masa pendidikannya di bawah bimbingan teolog

\footnotetext{
3 Annemarie Schimmel, Dimensi Mistik Dalam Islam, Terj; Team Pustka Firdaus, Jakarta: Pustaka Firdaus, 2009, hlm. 115.

4 M. Solihin, Epistemologi Ilmu Dalam Sudut Pandang Al-Ghazali, Bandung: Pustaka Setia, 2001, hlm. 20.

${ }^{5}$ Ahmadie Thaha, dalam pengantar terjemah Tahafut al-Falasifah, Loc. Cit., xiv.
} 
besar Al-Juwaini. Dan di bawah asuhan AlJuwaini ini, Al-Ghazali mempelajari ilmu fiqh, ushul, manthiq, dan kalam, filsafat dan tasawuf. Diduga, pada masa-masa ini pula, Al-Ghazali mempelajai praktik dan metode sufi kepada seorang guru bernama Al-Farmadzi. ${ }^{6}$

Selama tinggal di Naisabur Al-Ghazali tidak hanya belajar kepada Imam al-Haramain, tapi juga mempelajari teori-teori mengenai tasawuf lebih jauh kepada Yusuf an-Nasaj. ${ }^{7}$ Sedikitdemi sedikit ia mulai melakukan latihan dan praktik tasawuf, meski di tahap ini bisa dikatakan tak ada pengaruh yang signifikan terjadi selain sarana untuk melatih kedisiplinan diri.

Setelah Imam al-Haramain wafat (478M$1086 \mathrm{H})^{8}$, lalu Al-Ghazali pergi ke Muaskar (tempat istana wazir Nizam al-Mulk) di utara Naisabur, pada saat usianya mencapai 28 tahun. Diceritakan bahwa di masa ini Al-Ghazali telah menikah dan dikaruniai tiga anak perempuan dan seorang anak laki-laki bernama Hamid yang meninggal saat masih bayi. Itulah sebab kenapa Al-Ghazali juga sering disebut Abu Hamid. $^{9}$

Sebagai sorang yang ahli dalam bidang Mujadalah (retorika perdebatan), Al-Ghazali melibatkan diri pada perdebatan yang banyak dilakukan di sana dengan para ulama terkemuka. Di dalam perdebatan yang sering dilakukannya, Al-Ghazali tak jarang mengalahkan para ulama dengan mematahkan argumentasi-argumentasi yang mereka ajukan. ${ }^{10}$ Sehingga dengan demikian banyak di antara para ulama ini yang tak segan-segan mengakui keunggulan Al-Ghazali. Dengan kecemerlangan berpikir yang sedemikian rupa

6 Himawijaya, Mengenal Al-Ghazali For Teens: Keraguan Adalah Awal Keyakinan, Bandung: Mizan, 2004, hlm. 25-17.

7 M. Solihin, Epistemologi Ilmu Dalam Sudut Pandang Al-Ghazali, Op. Cit., hlm. 21.

${ }^{8}$ Sulaiman Dunya, Al-Haqiqah fi Naddzri al-Ghazali, Op. Cit., hlm, 30 .

${ }^{9}$ Ibid., hlm. 22.

10 M. 'Utsman Najati, Jiwa Dalam Pandangan Filosof Muslim, Bandung: Pustaka Hidayah, 2002, hlm. 202. Pada bab khusus mengenai Al-Ghazali. itu pada akhirnya membuat nama Al-Ghazali termasyhur di kawasan kerajaan Seljuk. ${ }^{11}$

Bakat Intelektual Al-Ghazali yang mencolok, akhirnya terlihat oleh wazir Nizam al-Mulk yang pada saat itu diberi kepercayaan penuh oleh Sultan Seljuk (Al Salajiqah) sebagai penguasa Khalifah Abbasiyah di Baghdad. Universitas Nidzhamiyah sendiri merupakan tempat pertemuan para ilmuwan dan dalam majelis ini keunggulan Al-Ghazali tampak menonjol. Akhirnya pada tahun $484 \mathrm{H}$ atau $1091 \mathrm{M}$, ia diangkat sang wazir sebagai guru besar di universitas Nidzhamiyah. Di kota ini, halaqah pengajiannya membesar disamping ia produktif dalam mengarang kitab yang menjadi fokus ketertarikannya.

Di universitas an-Nidzam, Al-Ghazali menjabat sebagai guru besar selama empat tahun. Pada usia 33 tahun ia telah mendapatkan salah satu kedudukan yang sangat istimewa di dunia akademis pada masanya. Periode ini menandai suatu tahap yang menentukan dalam hidupnya, sebab universitas memberinya lingkungan yang sangat menguntungkan untuk mengembangkan serta menyinari kepribadiannya. Di sana ia memperdalam pengetahuannya di bidang filsafat dan teologi. ${ }^{12}$

Pada masa-masanya menjadi guru besar, AlGhazali sangat aktif dalam mengikuti perkembangan juga perdebatan terhadap faham dan golongan-golongan yang berkembang di waktu itu. Di fase inilah benih-benih ketidak puasannya (nyaris skepstis) terhadap berbagai golongan yang mengatasnamakan keunggulan (dalam arti kebenaran) yang satu dengan yang lainnya mulai menguat. Hingga pada akhir masa kehidupannya ia sangat menguasai sendi-

${ }^{11}$ Ibid., hlm. 22.

12 Ada penggalan cerita di dalam perjalanan intelektual Al-Ghazali mengenai penyebab kenapa ia begitu menguasai cabang keilmuan pada zamannya: Konon suatu hari kediamannya disambangi maling. Yang mereka ambil selain harta, juga kitab-kitab berharga milik Al-Ghazali. Dari kejadian itu, Al-Ghazali kemudian bertekad untuk menghafal di luar kepala seluruh isi kitab yang dipelajarinya sehingga ia tak perlu susah-payah mengakses kitab yang telah ia pelajari meskipun kitabnya tak ada. 
sendi pergolakan faham yang terjadi pada saat itu, sehingga dengan hati-hati ia memilah mana yang pantas dan baik untuk dipegang dan mana yang kurang baik. Dalam otobiografi spiritualnya yang termasyhur Al-Munqidz min ad-Dhalal, ia menuturkan:

Sebelum meningkat ke umur dua puluh tahun hingga kini, dimana umuku sudah lebih dari lima puluh tahun, aku telah mengarungi samudera yang luas dan dalam itu, dengan keberanian yang tiada taranya... setiap kepercayaan dari berbagai macam golongan aku selidiki, aku coba menyelami kepercayaan masing-masing golongan agama sedalamdalamnya sampai ke rahasia hati mereka. Segala hal itu aku lakukan semata-mata terdorong untuk menarik suatu perbandingan antara yang haq dan yang bathil, yang sunnah dan yang bid'ah. Maka tatkala aku bertemu dengan kaum kebatinan (bathiniyah), akupun tertarik untuk menyelidiki kebatinan itu, demikian pula tatkala aku bertemu dengan kaum lahir (dzahiriyah), akupun tertarik untuk menyelidiki apa sesungguhnya yang dianut oleh mereka itu, dan apa ajran yang dimilikinya... Apabila mereka itu dari golongan filsafat, maka aku selami pula apa hakikat kefilsafaan mereka itu, begitupun ketika aku bertemu dengan orang dari golonga ilmu kalam (teologi), maka aku uji dan selidiki pokokpokok pemehamannya itu, demikian pula apabila yang aku temui golongan ahli tasawuf, maka aku jangkau inti dan rahasia-rahasia kesufiannya itu; apabila aku bertmu dengan golongan ahli ibadah (muta'abbid), aku tidak tinggal diam, melainkan aku pegang dasardasar praktek peribadahannya. Manakala aku

13 Al-Ghazali, Al-Munqidz min ad-Dhalal, Beirut: Dar al-Kutub al-Ilmiyah, 1988, hlm. 24-25.

${ }^{14}$ Ibid., hlm. 25.

15 Goenawan Mohammad lebih rinci menuturkan; Diketahui ia menulis beberapa buku yang menentang pemikiran kaum Ismaili, yang oleh musuh-musuhnya, juga oleh Al-Ghazali, disebut sebagai 'al-Batiniyah'. Salah satunya ditulis atas permintaan Khalif alMustazhir yang baru bertahta. Farouk Mitha (Mitha: 2001) menilai buku itu, Fada'ih al-Batiniyyah wa Fada'il al-Mustazhiriyyah ('Keburukan al-Batiniyah dan Kebajikan al-Mustaziriyah'), bukan saja disusun bertemu dengan golongan zanadiqah dan mu'athilah ('kafir' atau 'atheis'), maka aku pun mencoba memeriksa apa saja sebab-sebab juga latar belakang yang menjadi pegangan mereka itu. ${ }^{13}$

Al-Ghazali muda memang mempunyai ketertarikan yang sangat besar terhadap berbagai cabang keilmuan. Disamping itu semangatnya untuk menggapai suatu pengetahuan yang hakiki telah tertanam di dalam dirinya sedari dini. Ia menulis; "menghadapi masalah yang demikian tadi (menelusuri akar fundamental sebuah madzhab pemikiran) benar-benar sudah menjadi kegmaranku semenjak kecil, yakni menyelidiki dan membuat perbandingan untuk mendapatkan suatu hakikat." 14

Menurut Al-Ghazali, ada empat kelompok aliran pemikiran yang sedang berkembang pada masa itu, yakni kelompok bathiniyah, teolog dan filosof, juga kaum sufi. Mengenai yang pertama, Al-Ghazali berkepentingan secara politis karena satu dan lain hal. ${ }^{15}$ Lebih jauh, Al-Ghazali berpandangan bahwa kaum ini mempunyai tujuan politis yang terselubung disamping tidak mau mengakui peran akal budi dalam bidang pengetahuan secara ekstrem. Aliran ini menutup diri dengan hanya menerima realitas pengetahuan dari Imam yang ma'sum (terjaga), yang menurut mereka selalu ada pada setiap masa. Karenanya Al-Ghazali menandaskan; "prinsip aliran mereka dalah penolakan terhadap ra' yu (kebebasan berpikir dan berpendapat), penolakan terhadap fungsi akal budi... ilmu pengetahuan tidak bisa dimengerti kecuali dengan pengajaran (ta'lim)" ${ }^{\text {"16 }}$ Golongan ini berpandangan bahwa untuk menampik dalil-dalil keagamaan kaum Ismaili. Kitab itu juga bisa dilihat sebagai pelanjut tradisi siyāsa shari'yya, jenis risalah yang di masa itu merupakan usaha menawarkan teori politik dengan patokan hukum-dan, setidaknya dalam hal Fada'ih alBatiniyyah, merupakan argumen bagi kebutuhan dan keinginan untuk meneruskan sistem kekhalifahan. (Lihat, http//www.goenawanmohamad.com, dengan subjek judul $\boldsymbol{A L}$-Ghazali dan Kepastian).

16 Mahmud Hamdi Zaqzuq, Al-Ghazali Sang Sufi Sang Filsuf, Bandung: Pustaka, 1987, hlm. 5. Kutipan 
suatu sistem berpikir yang tidak terlebih dahulu ditransmisikan oleh guru yang ma'sum, maka hasil pikirannya tidak jernih dan tidak terjaga. Oleh sebab itu faham ini sangat meyakini bahwa untuk mengerti sebuah ilmu yang haq, maka perlulah pengajaran dari seorang yang ma'sum.

Keberatan Al-Ghazali mengenai faham ini dikarenakan akan menimbulkan semacam taklid buta di kalangan umum. Menurut AlGhazali pada hakikatnya imam yang ma'sum adalah simbol keterjagaan sebuah warisan intelektual, akan tetapi bukan berarti pengajaran dari sumber lain itu dengan begitu saja dapat ditolak. Dengan gigih Al-Ghazali mengajukan keberatan salah satunya karena tertutupnya kemungkinan seseorang untuk berijtihad. Lebih rinci Al-Ghazali memaparkan:

Menurut kebiasaan yang seharusnya, mereka memerlukan adanya pengajaran ( a $^{\prime} \mathrm{lim}$ ) dan guru (mu'alim). Menurut pendapat mereka tidak semua guru (mu'alim) itu cukup, akan tetapi pasti ada yang kurang di antara mereka... Kemudian timbullah argumentasi yang menyatakan perlunya seorang guru yang ma'sum. Sementara mereka menganggap lemah pada faham yang tidak sependapat dengan mereka... Mereka itu tidak menyadari bahwa anggapan dan pernyataan mereka itu sebenarnya disebabkan oleh karena lemahnya argumentasi pendukung yang benar. ${ }^{17}$

Dengan demikian menjadi jelas bahwa $\mathrm{Al}$ Ghazali mempunyai kecenderungan untuk berpikiran luas bahkan bisa disebut merasa risih dengan sikap yang taklid - sejauh orang dapat sedemikian rupa mengupayakan ijtihadnya sendiri. Dalam menerapkan contoh kebutuhan seseorang dalam berijtihad sehubungan dengan jarak yang membatasi seseorang untuk meminta nasihat mu'alim alma'sum, Al-Ghazali memaparkan contoh dari

Al-Ghazali di buku tersebut dari Fada'ih al-Batiniyyah wa Fada 'il al-Mustazhiriyyah, cet, Kairo 1964, hlm. 17.

17 Al-Ghazali, Al-Munqidz min ad-Dhalal, Op. Cit., hlm. 50. peritiwa Mu'adz Ibn Jabal ketika Rasul Muhammad mengutusnya ke Yaman. ${ }^{18}$

Sementara, kaum teolog secara umum adalah para pemuka agama yang ajaran-ajaran mereka terutama didominasi oleh akal budi, juga doktrin keagamaannya ditopang oleh rasio. Tujuan khusus kaum ini adalah untuk mempertahankan doktrin-doktrin keagamaan dari serangan musuh-musuhnya, seperti diutarakan Al-Ghazali:

Maksud dan tujuan almu kalam ialah untuk memelihara golongan ahli sunnah dan untuk menjaga dari percampuran dari golongan bid'ah yang menyesatkan. ${ }^{19}$

Akan tetapi Al-Ghazali pada akhirnya menemukan bahwa mereka tidak mewakili pemikiran intelektual yang mandiri. Malah, menurut Al-Ghazali, "mereka telah mendasarkan ajaran-ajaran mereka pada premis-premis yang mereka terima dari lawanlawan mereka. Mereka dengan terpaksa menerima premis-premis itu, ada kalanya mereka karena mereka memiliki sikap membeo (banyak bicara), atau karena adanya konsensus ummat (anggapan umum), atau sekedar menerimanya dari Al-Qur'an dan asSunnah". ${ }^{20}$ Mereka pada akhirnya terlalu jauh melenceng dari tujuan asal yakni menjaga dan mengembalikan semangat Tauhid dalam Islam.

Para teolog ini memang begitu gigih mengungkapkan ketidak konsistenan lawan dan mereka menguasai metode mujadalah (perdebatan) dengan sangat baik akan tetapi kurang mendalami kritik dan logika filsafat secara baik. Ranah kajian ini pada masa itu sangat digandrungi, sehingga kemelut yang diakibatkan oleh ambisi para teolog untuk mengungkapkan hakikat telah merebak di kalangan orang banyak. $^{21}$ Mereka-para teolog-mencoba untuk menjabarkan suatu hakikat dan Ketuhanan. Pembahasan mereka bahkan sampai pada jauhar (substansi) dan a'radh (sifat atau aksiden), akan tetapi mereka tidak mengalami kemajuan pemikiran yang

18 Ibid., hlm. 50

19 Ibid., hlm. 50.

${ }^{20}$ Ibid., hlm. 33.

${ }^{21}$ Ibid., hlm. 33. 
signifikan. Menganai hal ini Al-Ghazali menandaskan:

"Bukan tujuan mereka sehingga pembahasan mereka kurang mendalam dan luas, sedangkan hasilnya tetap tidak bisa menghapuskan kebingungan tentang perbedaan penciptaan." 22

Karena tidak mendapatkan kepuasan bagi jiwa dan intelektual yang memadai dalam apa yang dinamakan dengan ilmu kalam, AlGhazali berkesimpulan bahwa teologi tidak mampu mencapai pengetahuan yang hakiki, alih-alih malah membentuk kendala sehingga dengan metode ilmu ini seseorang tidak akan mengenal Allah secara hakiki. "Pengenalan Allah, sifat-sifat-Nya, dan tindakan-tindakanNya tidak akan tercapai lewat ilmu kalam. Malah ilmu ini menjadi penghalang dan pencegah darinya..."23

Setelah mendalami kalam (teologi rasional) dan tidak mendapati sesuatu yang hakiki dipelajari dengan matang di dalamnyaterutama disebabkan oleh krisis batinnya-AlGhazali mendalami filsafat. ${ }^{24}$ Dalam terminologi Arab Islam (Timur Tengah), filsafat seringkali diidentifikasi dengan sebutan al-hikmah. Akar kata ini sebetulnya bersinambungan dengan bahasa Yunani yang berarti cinta kebijaksanaan, karena hikmah dalam Islam menandai suatu pencapaian, bukan saja intelektual semata, lebih jauh bahkan pencapaian spiritual. Diceritakan bahwa ketika mendalami filsafat, Al-Ghazali bersinggungan langsung dengan karangan-karangan Al-farabi dan Ibn Sina. ${ }^{25}$ Dari sini ia mendalami logika peripatetik (Aristotelian), fisika dan matematika secara mendalam. Khusus menganai fisika, Al-Ghazali menunjukkan

22 Mahmud Hamdi Zaqzuq, Al-Ghazali Sang Sufi Sang Filsuf, hlm. 2.

${ }^{23}$ Ibid., hlm. 3.

${ }^{24}$ Al-Ghazali, Al-Munqidz min ad-Dhalal, Op. Cit., hlm. 33.

25 Terutama mengenai filsafat yang dikembangkan Ibn Sina sebagai filsafat peripatetik, Al-Ghazali berkepentingan menyanggah argumentasi yang rancu dan secara ekstrim bertendensi merobohkan fondasi aqidah pada masa itu. Ia secara bertahap menyusun logika peripatetik terlebih dahulu dalam Maqashid al- kecenderungannya yang lebih terpengaruh pemikiran Ikhwan as-Shafa (Persaudaaan Suci). ${ }^{26}$

Menurut pandangan Al-Ghazali menganai filsafat, setidaknya ada enam belas proposisi metafisika dan empat proposisi fisika yang memiliki relevansi jelas dengan agama, dan harus diperingatkan bagi orang-orang Islam yang lengah. Dari 20 proposisis yang hendak disangkal Al-Ghazali, tiga di antaranya sangat berbahaya dari sudut keagamaan, yakni keabadian alam (eternitas alam), pengetahuan Tuhan hanya pada yang Universal dan penolakan terhadap kebangkitan jasmani kelak di fase eskatologis (akhirat). ${ }^{27}$

Seperti diketahui, Al-Ghazali menentang kecenderungan para filosof pada masanya dan mengecam keras mereka. Kritik yang dilancarkan Al-Ghazali ini bukan karena kenyataan bahwa ajaran-ajaranfilsafat pada masa itu bisa melahirkan bahaya pada aqidah, tapi juga atas dorongan filosofis. Menurut AlGhazali, para filosof telah mengabaikan kesatuan akal budi, sebab setelah menetapkan syarat-syarat berpikir yang benar dalam logika, mereka tidak memakainya pada teologi (sistem aqidah). ${ }^{28}$

Pada saat puncak peraihan prestasi yang gemilang sebagai guru besar Nizhamiyah, AlGhazali mengalami sebuah krisis, yakni keraguan mendalam (skepstis) yang menjalar dan terlihat pada gejala-gejala fisiknya, meski tetap pada dasarnya bersifat religius. Bisa dikatakan bahwa pada fase ini Al-Ghazali mengalami perubahan orientasi hidup secara serentak dan drastis. Di titik ini ia menyadari bahwa pada saat ini tugas manusia yang paling penting adalah menghindari neraka dan

Falasifah demi memilah proporsi filsafat dan agama. Kemudian disusul dengan Tahafut Al-Falasifah yang mencoba menjelaskan kerancuan (tahafut) para filosof dalam mengajukan proposisi.

${ }^{26}$ Al-Ghazali, Al-Munqidz min ad-Dhalal, Op. Cit., hlm. 55.

${ }^{27}$ Ensiklopedi Tematis Dunia Islam, PT Ichtiar Baru Van Hoeve: Jakarta, 2003, hlm. 125. Mengenai AlGhazali oleh Muliadi Karthanegara.

28 Mahmud Hamdi Zaqzuq, Al-Ghazali Sang Sufi Sang Filsuf, hlm. 3. 
memperoleh surga. Akan tetapi ia sangat menyadari bahwa pada saat itu hidupnya terlalu duniawi untuk mengharapkan pahala keabadian. Perasaan batinnya mengalami tarikulur hingga pada akhirnya ia berketetapan untuk menjalani kehidupan zahid yang berkelana (suluk). Demikian ia menulis dalam Al-Munqidz:

Hampir mendekati enam bulan lamanya, yaitu mulai dari bulan Rajab tahun $488 \mathrm{H}$ (sekitar bulan Juli 1095), aku terus siombangambing oleh perasaan dan pikiran antara memilih kemegahan dan kesenangan hidup duniawi dan kebahagiaan hidup yang kekal abadi... Dengan takdir Allah bibirku menjadi kering, lidahku terasa terkunci sehingga aku tak sempat memberikan kuliah pada hari yang biasanya aku memberikan kuliah pada para pelajarku... Lidahku terkunci, tak sanggup lagi untuk bercakap-cakap walau sepatah kata... akibat yang lebih jauh lagi, yaitu perasaan sedih yang bergejolak di hatiku, dan sebagai akibatnya, kekuatan jasmaniku untuk mengunyah makanan atau untuk meminum air barang seteguk sangat lemah; pada akhirnya hilanglah nafsu makan dan minumku. ${ }^{29}$

Pada akhirnya, ia melkukan konsultasi atas masalah krisis batinyya yang mengakibatkan ia sakit pada tabib (dikter) di lingkungannya. Akan tetapi rupanya penyakit yang diderita AlGhazali, tak bisa diobati dengan obat-obatan fisik, melainkan harus diobati secara batiniyah. Al-Ghazali menuturkan:

Para dokter brusaha mencarikan obat untukku. "Kesukaran (penyakit) ini datangnya dari dalam hati (qalb) anda sendiri," demikian kata dokter itu kepadaku. Selanjutnya mereka berkata, "Dari hati itu kemudian ia menyebar dan menyelinap ke seluruh jiwa yang paling dasar, satu-satunya jalan untuk mengatasi dan mengobatinya tak lain melainkan anda harus

\footnotetext{
${ }^{29}$ Al-Ghazali, Al-Munqidz min ad-Dhalal, Op. Cit.,

${ }^{30}$ Ibid., hlm. 60

${ }^{31}$ Ibid., hlm. 61-62.
} hlm. 60 . memenangkan juga meredam keraguan atau kekhawatiran yang menjangkiti hati itu. ${ }^{30}$

Al-Ghazali akhirnya memantapkan diri untuk mengembara menempuh jalan sufi. Pertama-tama ia membagikan seluruh hartanya pada Baitul Mal, dan menyisihkan sedikit untuk keperluan keluarganya. Pengembaraannya ini memakan waktu sepuluh tahun meliputi kota Damsyiq (Syria), selama dua tahun ia tinggal di sini hanya untuk bertafakur di sebuah menara mesjid. Setelahnya ia berangkat ke Bait al-Maqdis (Madjid al-Aqsha) untuk melanjutkan khalwatnya yang kedua kali. Baru kemudian ia pergi ke Makkah dan Madinah untuk menunaikan ibadah haji, dari sini ia bertolak ke Hijaz sebelum akhirnya pulang kembali ke tanah kelahirannya. ${ }^{31}$

Sepulangnya dari pengembaraan, AlGhazali masih tetap melakukan khalwat di rumahnya. Diceritakan bahwa salah satu alasannya kembali adalah karena dipinta oleh Sultan untuk kembali megajar di Nizhamiyah, namun kegiatannya ini tidak berlangsung lama. ${ }^{32}$ Akhirnya ia kembali ke kampung halamannya, Thus. Al-Ghazali mendirikan sebuah perguruan di samping rumahnya dan khanaqah bagi kaum sufi. Ia kemudian mulai menulis karya-karya sufistik. Al-Ghazali kembali mengajar, namun perubahan yang terjadi akibat krisis batinnya bersifat permanen. Sekarang ia adalah seorang yang religius, bukan sekedar guru ilmu-ilmu agama. Ia wafat di Thus, kampung halamannya pada tahun $505 \mathrm{H} / 1111 \mathrm{M}$.

Dengan demikian, kehidupan Al-Ghazali dapat dibagi menjadi tiga rentang masa. Pertama ketika ia sebelum mengalami keraguan (skeptis) secara batin. Pada masa ini Al-Ghazali bisa dikatakan masih menyelami bentuk syari'at yang ditampilkan oleh berbagai fan (cabang) keilmuan. Begitupun secara kedudukan politis ia mendapatkan posisi yang

\footnotetext{
${ }^{32}$ Alasan sesungguhnya mengapa Al-Ghazali pulang ke kampung halamannya, seperti yang diugkapkan di dalam Al-Munqidz terutama dikarenakan permintaan anak-anak dan keluarganya. Al-Munqidz, Loc. Cit., hlm. 61-62.
} 
menguntungkan disamping mapan secara ekonomi dan masih menjabat sebagai seorang hakim (qadhi) dan juga guru besar (sekelas professor di masanya) di universitas anNidzam. Fase kedua terjadi pada akhir masa ketika ia hendak menanggalkan jabatannya sebagai guru besar dan mengalami keguncangan batin hingga membuat kesehatannya terganggu. Dikatakan bahwa pada titik ini ia mengalami produktifitas yang sangat signifikan dalam mengarang kitab mencakup ilmu kalam, filsafat dan berbagai cabang-cabang keilmuan disamping menjadi seorang pengajar syari'at (fiqh) terkemuka di Baghdad. ${ }^{33}$

\section{B. MISTISISME AL-GHAZALI SEBAGAI ETAPE SPIRITUAL}

Al-Ghazali tak berhenti di Filsafat dan studi Kalam, ia juga seorang hakim (ahli fikih) pada masanya; tapi ia lebih jauh melangkah. Dalam Al-Munqidz ia menetapkan kecenderungannya dalam corak pemikiran dan laku. Setelah selama hampir enam bulan pada masa hidupnya sebelum menempuh jalan sufi, ia terombangambing disamping kesehatannya menurun drastis. Pada akhirnya ia jatuh sakit total, tanpa tidak bisa disembuhkan dokter sama sekali. Syahdan, ia mengidap semacam krisis batin, penyakit psikologis yang tak ada obatnya kecuali dari dirinya sendiri. ${ }^{34}$

Saat itu, Al-Ghazali adalah seorang yang telah menyelami bahtera ilmu dengan dahaga yang tak berkesudahan dan hanya satu yang belum dia lakukan dan menghantui hatinya. Ia merasa belum lagi bisa mengamalkan apa yang telah didapatkannya selama menempuh jalan intelektual. Di dorong oleh adiknya, Ahmad, Al-Ghazali melihat ada jalan lain yang menjanjikan; bertasawuf. Selama ini, AlGhazali hanya membaca risalah sufi dengan nalar, ia bersentuhan setidaknya dengan karya

33 Sulaiman Dunya, Al-Haqiqah fi Naddzri alGhazali, Op. Cit., hlm. 56-59.

34 Al-Ghazali, Al-Munqidz min ad-Dhalal, hlm. 70.

35 Annemarie Schiemmel, Dimensi Mistik Dalam Islam, hlm. 106
Abu Talib Al-Makki ${ }^{35}$ Al-Junayd dan Abu Yazid Al-Bustham dan memahami ajaran pokok mereka. Ia mencapai konklusi bahwa, "dalam ilmu sufi ini tidak dapat dipahami jika hanya dengan mempelajarinya saja, melainkan ia harus disertai dengan amalan, (dengan) kegairahan yang penuh dengan semangat yang barkobar-kobar." 36

Al-Ghazali percaya bahwa para ahli sufi ini adalah, "mereka yang mengerti dan mempunyai pengalaman-pengalaman ilmu dan amal, bukan sekedar orang-orang yang pandai berbicara." Sekali lagi ditegaskan bahwa apa yang belum lagi dicapainya adalah, "mengamalkan penelaahan-penelaahanku itu, karena untuk mencapai kesempurnaan aku harus mengamalkan menurut jalan yang ditempuh oleh kaum sufi," yaitu bersuluk. Yang perlu dilakukan oleh Al-Ghazali adalah melakukan perjalanan sunyi. Dari sebagian sarjanawan muslim kontemprer menyebutkan bahwa apa yang dimaksud dengan perjalanan sunyi ialah melakukan 'hijrah'. ${ }^{37}$ Hijrah ini bukan dalam rangka sekedar melakukan perjalanan dan pakansi, melainkan titik tumpu seorang salik (orang yang bersuluk) dalam perubahan orientasi di dalam hidupnya. Dan inilah yang dilakukan oleh Al-Ghazali ketika ia harus menyembuhkan krisis spiritualnya. ${ }^{38}$

Motifnya bukan saja itu, Al-Ghazali mengungkapkan bahwa di dalam kesufian, orang diarahkan pada pola hidup sederhana dan mencukupkan diri dari hal-hal duniawi. Pendek kata, ia melihat situasi dan kondisi masyarakat pada saat itu dirasanya tidak memiliki kewaspadaan pada penyakit hati keserakahan dan kesenangan berlebih pada duniawi. Ia merasa terpanggil untuk menyelami lubuk hakikat, apa gerangan yang menyababkan agama Islam pada saat itu perlahan menyurut adalah kurangnya orang mukmin mereguk hakikat agama Islam yang dicontohkan Nabi saw.

\footnotetext{
36 Al-Ghazali, Al-Munqidz min ad-Dhalal, 58

37 Lihat, Al-Ghazali, The Alchemist of Happiness, Matmedia Production, a film by: Ovidio Salazar, Tt.

${ }^{38}$ Al-Ghazali, Al-Munqidz min ad-Dhalal, hlm. 70.
} 
Berkenaan dengan pandangan Al-Ghazali mengenai dimensi mistik (gnosis), ia menekankan beberapa aspek penting. Di antaranya ia meletakkan fondasi yang signifikan bagi perkembangan Gnostisisme Suhrawardi bahkan Ibn Arabi pada fase-fase berikutnya. ${ }^{39}$ Al-Ghazali ditakdirkan oleh waktu berada pada sufisme periode pertengahan yang berkembang pesat dalam kurun akhir kekuasaan Seljuk. ${ }^{40}$ Pandangan tasawufnya yang paling menonjol di antaranya penekanan pada corak amali. Al-Ghazali memadukan antara pengetahuan yang dihasilkan dari nalar kritis dengan intuisi dan menurunkannya ke ranah praktis. Kecemerlangannya dalam menjembatani sufisme dengan ortodoksi sunni menuai sambutan dan antusiasme yang baik di khalayak. ${ }^{41}$ Meski tak bisa dipungkiri banyak pula yang menudingnya sebagai penyebab mundurnya rasionalisme filsafat di dunia Islam. Tapi pandangan yang terakhir kiranya kurang dapat dipertanggung jawabkan karena pada kenyataannya, bahkan setelah ia berada dalam sufisme, pandangan filsafatnya masih sangat kental.

Menurut Margareth Smith, Al-Ghazali sedikit banyak terpengaruh oleh ajaran neoPlatonisme. Pengaruh ini terutama sangat jelas di dalam karya-karya mistis Al-Ghazali. Dari Plotinus ia memangbil konsep Tuhan sebagai Wujud Yang Maha Satu, Sumber Segala Makhluk, Maha Sempurna Dalam Sifat dan Wujud. Dia Adalah Esa, Yang Pertama dan Terakhir, Dzahir dan Batin. Dia tidak berbentuk, baik substansi maupun aksiden, tidak pula ada wujud yang menyerupai-Nya. Dia tidak mengambil suatu tempat di mana pun dan tidak ada sesuatu pun yang menempatiNya. Terlalu agung untuk dikatakan bertempat,

39 Annemarie Schiemmel, Dimensi Mistik Dalam Islam, hlm. 329. Demikian Schiemmel merekam; Aliran utama tasawuf ortodoks yang moderat disistematisasikan oleh Al-Ghazali, namun karya-karya Al-Ghazali sendiri mengandung pandangan yang nantinya akan dikembangkan penuh dalam aliran teosofi Islam. Karangannya yang berjudul Misykat Al-Anwar, adalah buku yang dipakai titik awal oleh kebanyakan sufi di kemudian hari. dan terlalu suci untuk dikatakan terkurung waktu. Dia Wujud sebelum waktu dan tempat diciptakan. Dia mandiri, dengan sendirinya. ${ }^{42}$

Kecenderungan Al-Ghazali lebih lanjut terhadap doktrin emanasi juga berasal dari ajaran neo-Platonisme. Dia mengatakan tentang kesatuan wujud sebagai keragaman, dia juga berpendapat bahwa keragaman yang ada sebagai limpahan dari Yang Satu, Yang Tertinggi. Lebih lanjut ditegaskan bahwa Dia adalah Tuhan sebagai Yang Pertama dari sekalian wujud yang ada, sebab semuanya merupakan Emanasi dari-Nya. ${ }^{43}$

Al-Ghazali mendasarkan ajaran tasawufnya pada olah jiwa atau nafs. Manurutnya, jiwa manusia memiliki sejumlah potensi yang tertanam di dalamnya. Jika ditarik dari garis pengaruh pemikiran Plotinus, Al-Ghazali terindikasi mengadopsi pemikiran bahwa Jiwa manusia memiliki aspek Ilahiyah. Sampai di sini kita akan keluar dari keterpengaruhan AlGhazali oleh Plotinus. Al-Ghazali dengan pemahamannya yang paling mendasar pada AlQuran dan Hadis kiranya sudah sangat cukup dalam bekalnya mengembangkan ajaran tasawufnya sendiri yang paling vital. AlGhazali menganggap bahwa jiwa manusia memiliki aspek ketuhanan karena ia merupakan khalifah dan citraan Allah. Mengambil skema plotunian dirasa terlalu jauh meski tak dipungkiri keterpengaruhannya oleh filsafat Yunani terutama Peripatetik. Seperti telah dikemukakan di muka bahwa pada dasarnya di dalam tubuh Islam sendiri, ajaran Tauhid mengandaikan skema baik itu secara rasional dan atau pun intuitif. Sangat penting ditekankan bahwa di dalam Al-Quran kecenderungan dalam berpikir sangatlah dikedepankan, ini mencirikan aspek rasional peripatetik. Sedang di satu aspek, penerimaan

${ }^{40}$ Hamid Dabasyi, Sufisme Persia dalam periode Seljuk. Yogyakarta: Pustaka Sufi, 2003, hlm. 13-20

${ }^{41}$ Lihat Ensiklopedi Tematis Spiritualitas Islam, Jilid 1. hlm. 208. Lihat juga, M. Smith, Al-Ghazali The Mystic, hlm. 259.

${ }^{42}$ M. Smith, Al-Ghazali The Mystic, hlm. 117-18.

${ }^{43}$ Ibid., 118, Bdk, Misykat, hlm. 38-39. 
akan Tauhid mengandaikan aspek yang sangat intuitif dan ini mengindikasikan aspek Platonian dan Plotinus.

Mengenai penekanan Al-Ghazali pada aspek perkembangan jiwa, ia mengembangkan pembahasan ini dalam terminologi nafs almuthma'innah dan nafs al-lawwamah. Yang pertama meruapak jiwa terpuji, ia merupakan aspek suci secara ruhaniyah, kadang juga diidentifikasi sebagai jiwa Rasional yang diidentikkan dengan hati dan ruh manusia yang berasal dari Allah. Ang selanjutnya adalah jiwa tercela yang secara umum mendominasi kehidupan manusia pada umumnya, dengan hati nurani yang cenderung mengajak pada halhal yang rendah. Yang ketiga dari aspek jiwa ini dalah jiwa kebinatangan (nafs al-amarah, yang erupakan jiwa irrasional yang penuh dengan ego dan dikuasai oleh sifat-sifat kebinatangan. Ajaran kosmologi Al-Ghazali terdiri dari atas alam malakut (dunia ruhani), alam jabarut (dunia selestial) dan dunia material (alam al-mulk wa as-syahadah). Ketiga pembagian ini merupakan dasar-dasar pokok ajaran tentang kosmologi dan tasawuf Al-Ghazali dalam rangka mengembangkan jiwa atau nafs di dalam diri manusia. ${ }^{44}$ Ajaran ini merupakan ajaran yang selaras dengan prinsip-prinsip dasar mengenai tahapantahapan pendakian menuju Ma'rifat Allah.

Al-Ghazali secara konsisten juga menggunakan perumpamaan cahaya. Disamping konsep cahaya yang diambil dari Al-Quran, cahaya juga diidentifikasinya sebagai cahaya pengetahuan yang merasuk ke dalam hati. Bahkan pengetahuan secara umum dimungkinkan oleh adanya cahaya yang 'menerangi' sesuatu sehingga sesuatu tersebut sampai kepada pengindra. Lebih jauh, AlGhazali mengibaratkan pengetahuan yang hakiki adalah ketercerahan yang datang dari atas. Sebagaimana Allah adalah Sumber Segala Cahaya, Dia juga merupakan yang memprakarsai manusia dalam mengetahui. AlGhazali lebih lanjut juga mengatakan cahaya bumi berasal dari cahaya langit yang pada giliranny sampai pada Cahaya Tertinggi (Nur Al-Aqsha al-A'la), yang tiada lagi cahaya di atasnya, bahkan Dia yang menyinari segala wujud yang ada.

Kebalikan dari cahaya adalah kegelapan. Kegelapan pada dirinya sendiri adalah ketiadaan total. Sedangkan di dalam terminologi cahaya, kegelapan hanya mungkin jika ia kekurangan cahaya. Bahwa sejatinya Cahaya Segala Sesuatu adalah Allah, karenanya segala sesuatu yang dihasilkan dariNya hanyalah bias. Keberadaannya sebagai wujud hanyalah pinjaman, adalah sesuatu yang diberi yang sumbernya adalah Al-Haqq; Allah. Wujud Cahaya pada dirinya sendiri juga adalah sesuatu yang menerangi. Cahaya Sejati Terang oleh dirinya sendiri sedangkan cahaya selain dari-Nya memiliki sumber. Contoh sederhana dari ini adalah cahaya dari pelita adalah minyak, cahaya dari matahari adalah panasnya; bahwa semua itu memiliki sumber yang membuatnya terbakar.

Karenanya cahaya juga memiliki tingkatantingkatannya yang tersendiri. Segala cahaya yang berada di dalam alam syahadah memiliki sumbu dan sumber dan tentu saja memiliki keterbatasan menerangi dan waktu menerangi. Di dalamnya ada mineral-mineral, tetumbuhan, hewan dan manusia. Sesuai dengan fitrahnya sendiri-sendiri, semua itu juga memiliki cahaya pada dirinya sendiri. Tapi dalam kasus manusia, ia mempunyai akses yang memungkinkannya melampaui keterkondisiannya sebagai makhluk jasmani. Ada dua aspek lain yang tertanam di dalam diri manusia slain keterbatasan jasmani yaitu $R u h$ dan Aql. Yang jika kedua instrumen ini diaktifkan dan 'digosok', niscaya ia akan memantulkan Cahaya Hakiki. Contoh sempurna dari manusia yang telah melakukan ini adalah para Nabi dan Urafa' (jamak dari 'Arif). Jika daya ini diaktifkan, ia akan mampu menembus langit-langit malakut yang dimensi cahayanya lebih jernih dan murni. Akhir dari pendakian dan tujuan segala bias cahaya, baik itu cahaya kebumian dan maupun cahaya

${ }^{44}$ M. Smith, Al-Ghazali The Mystic, hlm. 119. 
malakut adalah Allah: Sumber Dari Segala Cahaya. ${ }^{45}$

Di dalam naskah-naskah Al-Ghazali yang lebih esoteris mengungkapkan bahwa aspek yang membuat manusia bukan saja harus melakukan perjalanan menuju Yang Hakiki. Aspek tersebut yang terutama tertanam di dalam diri manusia adalah aspek cinta. AlGhazali mengungkapkan bahwa segala sesuatu menuju pada Al-Haqq di antaranya disebabkan ada aspek cinta yang menarik segala sesuatu mengkutub pada-Nya. ${ }^{46}$ Akan tetapi, seperti bisa dibayangkan dari pengembraan biasa, orang akan teralihkan dari Yang Hakiki ke yang Majazi. Al-Ghazali mengungkapkan bahwa dalam rangka menuju Yang Hakiki manusia harus dibersihkan dari segala sesuatu yang menghambat dan yang membuatnya terkondisikan. Di dalam realitas fisik, pertanatama manusia harus dibersihkan dari kesalahan persepsi yang bersifat indrawi. Dari sini, manusia harus juga dibersihkan dari kesalakankesalahan berpikir dan mengambil konklusi. Tidak hanya di sana, Al-Ghazali mengemukakan bahwa manusia harus juga melepaskan diri dari kesalahan persepsi yang dihasilkan dari daya imajinasi (almukhayyilah). Di titik ini kemampuan manusia sebagai yang menubuh masih terkondisian.

Al-Ghazali mengungkapkan aspek lain, yaitu Ilham atau pancaran Ilahiyah yang memantul di dalam hati dan jiwanya. ${ }^{47}$ Tapi pertama-tama hati juga harus dibersihkan dari segala macam hasrat duniawi, amarah dan tiap hal yang membuat hati menjadikan tercemar. Sekai lagi ditekankan, ia harus digosk

\footnotetext{
45 Al-Ghazali, Misykat, hlm. 39-40.
}

46 Di dalam Kimya As-Sa'adah, Al-ghazali menegaskan bahwa; "Cinta Kepada Allah merupakan petunjuk tertinggi." Meski demikian Al-Ghazali mengungkapkan beberapa pokok hal yang membuat seseorang tidak mencintai Allah. Tapi di antara yang membuat seorang hamba cinta kepada Allah antar lain, petama karena ia mencintai dirinya sendiri dan selalu dalam 'proses' menyempurnakan sifat perbawaannya. Yang kedua adalah karena manusia suka kepada yang suka menolong kepadanya, dan sesungguhnya satusatunya yang memberi pertolongan hanyalah Allah yang maha pengasih. Sebab selanjutnya ialah suatu kedaan sedemikian rupa sehingga dapat memantulkan Cahaya Al-Haqq. Sampai di sini, Al-Ghazali seakan-akan akan berhenti dalam mengupayakan kemenujuan pada Allah. Rupanya Al-Ghazali melangkah lebih jauh, ia menawarkan realitas fana al-fana, (Kemeleburan Seutuhnya). ${ }^{48}$ Doktrin inilah yang dikembangkan lebih mutahir kelak menjadi Wahdat Al-Wujud oleh Saikh AlAkbar Ibn Arabi (638H/1240M) dan berpusat di Insan Al-Kamilnya Abdul Karim Al-Jilli $(832 \mathrm{H} / 1428 \mathrm{M})$.

Tapi Al-Ghazali tak silap, ia tidak dengan begitu saja bertengger di menara gading kesufiannya. Periode Uzlah selama sektiar sepuluh tahun lebih, tak membuatnya melepaskan diri dari konteks kebermasyarakatan pada saat itu. Ia kembali, tapi tentu saja tidak sebagai Al-Ghazali yang dulu. Kini ia adalah 'arif billah (seorang arif di jalan Allah). Ia menetapkan dengan mantap bahwa; "kaum sufi itu adalah orang-orang yang khusyuk menempuh jalan mendekat kepada Allah; kehidupan mereka adalah yang terbaik, akhlak mereka adalah yang paling murni. Sungguh manakala terkumpul para ahli pikir cerdik-cendikia, para hukama (ahli-ahli hukum), kemudian kepada mereka diminta agar supaya mengadakan perubahan akhlak mereka yang mendalam, merubah dengan akhlak yang lebih baik daripadanya, niscaya mereka tidak akan sanggup mencapai seperti yang dicapai oleh kaum sufi." ${ }^{49}[]$

dimana seseorang bertafakur pada sifat-sifat kekuasan dan keluasan Allah. Sedangkan sebab yang terakhir adalah adanya pertalian antara Allah dan Manusia. AlGhazali, Kimya As-Sa'adah, Terj Rus'an, Jakarta: Cv. Mulya, 1964, hlm. hlm. 422-24.

${ }^{47}$ Ibid., hlm. 419. Demikian Al-Ghazali;

"Kesempurnaan manusia terletak dalam hal bahwa dengan mencintai Allah manusia dapat menguasai jiwanya, dan setidak-tidaknya dapat mengurangi rasa cinta terhadap perkara lain."

${ }^{48}$ Al-Ghazali, Misykat, hlm. 43.

${ }^{49}$ Al-Ghazali, Al-Munqidz min ad-Dhalal, hlm. 62. 


\section{DAFTAR PUSTAKA}

Abu Hamid Al-Ghazali, Misykat Al-Anwar. Bandung: Mizan, 1984.

, Munqidz Min Ad-

Dhalal, Beirut: Dar Al-Kutub Al-Ilmiyah, Tt. , Ma'arij Al-Qudsy fi

Madarij Fi Ma'rifat An-Nafs, Tp, Tt.

Bandung: Marja, 2010. , Tahafut Al-Falasifah,

Jakarta: CV. Mulja, 1964.

Kimya As-Saadah,

Al-Ghazali, The Alchemist of Happiness, Matmedia Production, a Film by: Ovidio Salazar, Tanpa tahun produksi.

Annemarie Schiemmel, Dimensi Mistik Dalam Islam, Jakarta: Pustaka Firdaus, 2009.

Hamid Dabasyi, Sufisme Persia Dalam Periode Seljuk, Yogyakarta: Pustaka Sufi, 2003.

Himawijaya, Mengenal Al-Ghazali For Teens: Keraguan Adalah Awal Keyakinan, Bandung: Mizan, 2004.

Ibn Sina, Ahwal An-Nafs Risalah Fi An-Nafs Wabaqa'iha Wama'adiha, Yogyakarta: Pustaka Hidayah, 2009.

Margaret Smith, Al-Ghazali The Mystic, Jakarta: Riora Cipta, 2000. Reading From Mystic Of Islam, Bandung: Pustaka Hidayah, 2007.

Goenawan Mohamad, dalam http//www.goenawanmohamad.com, dengan subjek judul AL-Ghazali dan Kepastian).

Goenawan Mohamad, dalam http//www.goenawanmohamad.com, dengan subjek judul Tentang Atheisme dan Tuhan yang Tak Harus Ada

M. 'Utsman Najati, Jiwa Dalam Pandangan Filosof Muslim, Bandung: Pustaka Hidayah, 2002.

M. Solihin, Epistemologi Ilmu Dalam Sudut Pandang Al-Ghazali, Bandung: Pustaka Setia, 2001.

Seyyed Hossein Nasr, (Ed.), et. al, Ensiklopedi Tematis Spiritualitas Islam, Jilid 1, Bandung: Mizan, 2002.

Sulaiman Dunya, Al-Haqiqah Fi Nadzri AlGhazali, Mesir: Dar Al-Ma'arif, 1971. 